\title{
Professional Identity Development of Student Teachers in Finland, Norway and Australia
}

\author{
Rita Riksaasen ${ }^{1}$, Leanne Crosswell ${ }^{2}$, Denise Beutel ${ }^{2}$ \\ NTNU, Norway ${ }^{1}, Q U T$, Australia ${ }^{2}$
}

\begin{abstract}
Teachers' perceptions of their professional identities influence their sense of self-efficacy and as well as impacting on their classroom practices. The construction of professional identity is reliant on socio-cultural settings as well as on individual differences and so is dependent on the different national contexts. Professional identities of teachers begin to emerge during preservice teacher education. This study explored how the different economic and cultural conditions influence the formation of teacher professional identity across three national contexts. In this multicultural qualitative study, 29 student teachers across Norway, Finland and Australia were interviewed to identify their motivations for wanting to become teachers and how their different upbringings impacted on the ways in which they would engage students in their classrooms. Significant differences between the student teachers in the three national contexts emerged from the data. The findings are discussed in the paper in relation to Bernstein's theory of educational codes and Bourdieu's notion of habitus.
\end{abstract}

\section{Introduction}

The literature is replete with articles about the professional identity development of teachers and of student teachers. However, there appears to be a lack of literature that examines the contextual nature of professional identity development. In their review of the literature, Beijaard, Verloop and Vermunt [1] highlighted the significance of situational and contextual factors in teachers' professional identity development. Professional identity refers to "how teachers view themselves as teachers; how teachers view others that they professionally engage with; and how teachers believe they are perceived by 'others' [7] (p. 432)

Sachs [16] argues that teacher professional identity provides a framework for teachers to construct their own ideas of how to be, how to act and how to understand their work and their place in society. Teachers' perceptions of their own professional identity influence their self- efficacy as teachers as well as on their classroom practices [1].

Professional identity refers to what student teachers themselves find important in their future professional work and lives, based on both their experiences in practice and their personal backgrounds. Early child experiences, early teacher role models, previous teaching experiences and significant others (such as parents, work colleagues and friends) as well as prior workplace experiences contribute to professional identity formation [22]. More recent research has also acknowledged that the professional identity construction of student teachers is a social process deeply rooted in the life histories of students [21]. For example, Bukor [6] concludes that teachers' professional identities result from the "complex interconnectedness of one's cumulative life experiences as a human being" (p. 305).

Czerniawski [7] posits that teacher identity and its construction varies from country to country as it is reliant on socio-cultural settings as well as individualistic influences. Socially constructed identities are created in national pedagogic traditions, national policy contexts and institutional settings. Beijaard et al. [1], suggest that more attention should be paid to the role of context in professional identity formation.

This paper is based on semi-structured interviews with 29 student teachers taking a on-year full time or a two-year part time graduate entry teacher education program. The Finnish and the Norwegian student teachers were preparing to teach in lower and upper secondary schools, while the Australian student teachers were preparing for teaching in the middle years of primary school. The paper explores the research questions: What is the motivation of the individuals to become teachers? How will student teachers engage students in learning in their future work? What perspectives on upbringing do student teachers bring to teacher education? 


\section{Teaching in an international context}

Teaching and teacher professionalism vary between countries. Hargreaves [8] suggests that it is the struggles between and within modernity and postmodernity that the challenge of change for teachers is to be found. These competing and conflicting forces act on the teaching identities which student teachers construct and this has significant consequences for their attitudes and approaches to teaching. Teaching identities within a postmodern framework are part of a discourse which is open to continuous redefinitions. This vision of professionalism contrasts with the modernist, more restricted concepts of the professional teacher as someone who simply needs to possess the "right" methods for securing classroom control, such that teaching and learning may occur, namely the ability to maintain pupil attention, to secure coverage of subject content, to motivate pupils and to provide them with some degree of mastery [9]. It is important to note that a modernist view, albeit in "postmodern clothes" continues to co-exist alongside the activist view of teacher professionalism.

Bernstein [2] proposed that individual behavior can only be interpreted in the light of membership in a social group and family. Families and schools are influenced by different codes. A code is a regulative principle, tacitly acquired, which selects and integrates relevant meanings, the forms of their realization and evoking contexts." [3] (p. 14).

According to Bernstein [2] an educational knowledge code concerns legitimate and illegitimate communication in a pedagogic context. The curriculum defines what counts as valid knowledge, pedagogy defines what counts as the valid transmission of this knowledge, and evaluation defines what counts as a valid realization of the knowledge on the part of the learner. The form of the educational code depends upon the social principles that regulate the classification and framing of knowledge. Classification refers to the relationship between categories rather than what is classified [3] Classification can be strong $(+\mathrm{C})$ or weak $(-\mathrm{C})$, according to the degree of insulation. If there is weak insulation between categories, the categories are less specialized and their distinctiveness is reduced.

Framing is used to determine the structure of the message system, the pedagogy. Framing can be strong or weak. Analytically, we can distinguish two systems of rules regulated by framing. They are the rules of the discursive order, the instructional discourse, (selection, sequencing, pacing and criteria), and the rules of the regulative discourse (control over the social base). The strength of classification and the strength of framing can vary independently of each other.

If a teacher combines strong framing and strong classification there will often be a visible pedagogy.
A visible pedagogy is based on a performance model in which the teacher is concerned with transmitting specific skills (performances). The existence of firm, explicit criteria makes evaluation rather easy to measure. There is a hierarchical organisation of knowledge, and a key discipline concept. Discipline means accepting a given selection, organisation, pacing, and timing of knowledge realised in the pedagogical framing. The evaluation system places emphasis on attaining states of knowledge rather than ways of knowing, and on what is missing in the product [3].

If a teacher or a parent combines weak classification and weak framing, there is what is termed as an invisible pedagogy. The control over the student or the child is implicit rather than explicit [3] [4] [14]. In an arranged context, the child/ student arranges his or her activities to enable shared competencies to develop [3], There is an inbuilt procedural democracy, an inbuilt creativity, and an inbuilt virtuous self-regulation. The criteria for evaluation in an invisible pedagogy are multiple and diffuse. An invisible pedagogy is based on a competence model [3].Competence models have a critical, skeptical view of hierarchical relations.

An invisible pedagogy corresponds to an invisible and implied code. According to Bernstein [3], "code" bears some relation to Bourdieu's concept of habitus. The concept of habitus is a more general concept. It is essentially a cultural grammar specialized by class position and fields of practices. "Habitus" is specifically constituted in Bourdieu's account as:

"The conditions associated with a particular class of conditions of existence produce habitus, systems of durable, transposable dispositions, structural structures which generate and organise practices and representations that can be objectively adapted to their outcomes without presupposing a conscious aiming at ends or an express mastery of the operations necessary in order to attain them. Objectively "regulated" and "regular" without being in any way the product of obedience to rules, they can be collectively orchestrated without being the product of the organising action of a conductor" [4] (p. 53)

"Habitus" is a product of history which produces individual and collective practices. Habitus sets the boundaries within which agents are "free" to adopt strategic practices [10]. These practices, based on the intuitions of the practical sense, orientation rather than strictly determining action. A "code" like a habitus is tacitly acquired during socialisation. It does not direct behaviour, but influences behaviour in any pedagogic context.

In the present study, the code theory of Bernstein and Bourdieu's theory about habitus will support the analysis of student teachers' perspectives on teaching and upbringing both on a micro and macrolevel. 


\section{Three national contexts}

Finland's first National Curriculum for comprehensive schools was introduced in 1952. In the Finnish system, teachers are responsible as professionals for developing their own teaching methods and content.

The teaching profession in Finland is highly respected, and the recruitment to teacher education is from the most highly qualified university students. Primary school teachers as well as secondary and special education teachers must hold a Masters degree. For 30 years, teacher education in Finland has been a strong academic university-based program with a research orientation. Specific schools are appointed as university practice schools, and the supervisors in these schools are university lecturers. While the state authorities have the monopoly for accrediting teachers, Finnish teachers are autonomous professionals who build their practice on research-based knowledge and ethical values. According to Simola [17], Finnish teachers identify with the upper social strata, and their political opinions are rather conservative.

Studies of Finnish schools show that the teaching is often based on what Bernstein would call a visible pedagogy. Finnish culture still incorporates an element of an authoritarian, obedient and collectivist mentality [17]. Both in Finland and Norway, 98\% of students go to public schools, and no student teachers pay fees for their university or college education.

Norway had their first national curriculum introduced in 1935. Since then, the State has initiated and revised curricula, for example in 1974, 1987 and 1997. In 2006, a new National Curriculum was introduced. Similar to the Finnish system, teachers in Norway are responsible for developing their own teaching methods and content. However, Norway has a long tradition of more detailed curricula with more explicit descriptions of content to be taught. While students take part in national tests in basic skills, the curriculum has not been connected to standards for national evaluation.

Norwegian schools are comprehensive. These schools are underpinned by a belief that all people are equal and should be treated as such [18]. This strong belief in equality has contributed to teachers not wanting to be seen as having a status above others. Previous research has characterized the Norwegian education system as one in which equality is valued over and above cultural and academic achievements [19]. In Norway, teacher education embraces an anti-authoritarian approach to teaching which has embedded strongly within the teaching profession.

Norwegian education has embraced positive learning environments, intrinsic motivation and selfregulated learning (according to an invisible pedagogy)[13]. Student teachers complete their teaching practice in public schools, where supervision is often based on an invisible pedagogy [15].

Australia's National Curriculum was introduced in 2014. Prior to this, the education authorities in each state and territory developed their own curriculum. While there is a national curriculum, each state may determine the curriculum implementation timelines for their own schools. The curriculum contains content descriptors that specify what all young people should learn and what teachers will teach. Achievement standards set out the depth of understanding and sophistication of skills expected of students at specific points in their schooling.

There are a number of contrasts between students in Australian schools and those in Finland and Norway. For example, in Australia only $66 \%$ of students go to public schools, with $20 \%$ attending Catholic schools (often with separate girls and boys schools) and $14 \%$ attending independent schools. Another difference also is that the vast majority of Australian schools require students to wear a school uniform. A school uniform may signal different schooling contexts, for example, if a student goes to a progressive private school or a conservative catholic school.

In contrast to the Nordic countries, Australian university students have to pay for their university studies and teacher education. As the English is becoming a world language, it is relatively easy for Australian teachers and students with university degrees to work abroad, not only in English speaking countries, but also for example in many Asian countries.

In Australia, national professional standards for Teachers (APST) were introduced in 2013. The Australian Professional Standards for Teachers (APST) define the criteria for teacher registration, and outline what teachers should know and be able to do across three domains: Professional knowledge, professional practice and professional engagement. It is argued that the Australian standards provide a common base for assessing teaching performance. Teachers must meet the graduate standards of performance, as measured against the Australian Professional Standards for Teachers, on graduating from their teacher education program. At this point, graduating teachers may apply for provisional teacher registration. To apply for full teacher registration teachers must meet the next level of performance, Proficient, of the professional standards and have completed at least 200 days of teaching in an Australian schooling context.

\section{Method}

As the study focuses on student teachers' perspective on professional identity formation in 
three countries, the study can be classified as multicultural research [12].

This qualitative study is based on 29 semistructured interviews. The sample consisted of eight Finnish student teachers (FST), nine Norwegian student teachers NST and twelve Australian student teachers (AST). In Finland and Australia, student teachers were invited to participate in the study through an announcement on the relevant learning management system. In Norway, the sample of student teachers was selected by sending an email directly to the student teachers.

The purpose of the interviews was to reveal the student teachers' reasons for having chosen teaching and to study how their earlier experiences from family and work as well as the national context would impact on their teaching and professional identity formation. Open-ended questions were included in the interviews, with opportunities for to the participants extend and substantiate their responses. An interview guide was constructed and used initially in Australia. Subsequently, the study was extended and the same interview guide was used in the study of the Finnish and Norwegian student teachers. The interviews took place as a conversation in which the sequencing and selection of questions could vary.

All the Norwegian and Finnish interviews were face to face, while half of the Australian interviews were conducted by telephone. Every interview made face-to face lasted for about one hour while the telephone interviews lasted for approximately 45 minutes. English was the interviewer's second language, and body language is especially important when communicating in a foreign language. Thus, the information in the telephone interviews was more restricted. The Finnish interviews were influenced by English as a second language both for the informants and interviewer. However, slow pacing in all interviews contributed to positive communication.

All the interviews were tape recorded and transcribed. The responses of the Australian participants were read by the three researchers. The responses of the Finnish and Norwegian student teachers were read and coded by Riksaasen. All the interviews were initially hand coded. Then using a process of comparison, the data was re-coded and grouped. Similarities and differences in the data emerged [12]. The code theory of Bernstein and the theory of Bourdieu about habitus weas used in the analyses.

In the data analyses it became clear that student teachers' earlier experiences influenced their identity formation.

\section{Results}

The analysis has contributed to an awareness of how national context influences professional identity formation, thus the findings are introduced within the different national contexts in which the student teachers were situated.

\subsection{Finland}

Almost all the FST (7 out of 8) revealed that they wanted to become teachers because of their strong interest in their subject and because they also wanted to work with people. Four of the FST said that they want to be teachers instead of researchers. For example "Una" had worked in forest research previously. Originally, she thought she would enjoy that work, but she felt unhappy and believed that being a teacher would be more meaningful.

A second student "Wilma" decided to become a teacher when she studied Biology. She was interested in many different aspects of this subject and stated that she did not want to specialize in a specific area but said she wanted to become a teacher: "Because I like biology I like teaching, and I thought I would be good at teaching young students."

A third student, "Ann emphasized her love of her subject, French, and expressed concern that she might love her subject more than teaching Ann also stressed different teaching methods and positive communication as important to teaching. If students are going to talk French, the teacher has to talk French. Teaching in Finnish schools is often based on textbooks and Ann complained that the teaching material in the classrooms was not new. Ann had also studied media previously and was very familiar with using technology and was concerned about the lack of computers in her classroom. When the FST were asked the question "How will you engage students in learning" they were still oriented to their subject. For example, "Eva" says she wants to make her subject Biology interesting by using examples from the students' everyday life (weak classification between school knowledge and everyday knowledge).

The FST must understand that the subject has relevance beyond the classroom and is not just about something in the textbook. These student teachers indicated that students have to learn to explore and learn by doing and so their approach to teaching Biology was through a student-centred approach which involved students doing lots of experiments and going on excursions.

Several of the FST described traditional teaching (based on a visible pedagogy) during their practice terms. One of the FST says that "progressive" ideas are stopped in these university schools. The teachers and supervisors in the university schools, who have been appointed teachers because they were competent teachers several years ago, contribute to a reproduction of the traditional teacher-directed approach during teacher education Several FST 
complained of an unrealistic practice in the university schools.

An intention with this study was to explore what student teachers bring to teacher education. How did earlier experiences from family and work influence identity formation? The student teachers were also asked the question: Do you have the same perspective on upbringing as your parents? As the interviews were organized as a conversation, the follow up questions were directed to study the forms of control the student teachers had experienced in their family. For example, did your parents practice rules during their upbringing?

The results from the study show that 21 out of 29 student teachers had similar perspectives on upbringing as their parents. From the FST five stated that they had the same perspective on upbringing as their parents, while two said they wanted more rules and a stricter upbringing than their own. One of the students did not respond to this question. Below are examples from the interviews that illustrate how family experiences influenced these student teachers.

"Lea" a FST had a mother with university education and a father who was a businessman. Lea thought her parents taught her good habits and that this contributed to her self-confidence. When Lea was asked about what happened if she broke a rule, she says her parents tried to behave like positive models. For example, while she was not allowed to drink alcohol, if she did drink, her parents understood that children had to break rules from time to time. Lea considered that it is important for parents not to be too strict as children may then lie for their parents.

"Unni", another FST was the only child of parents who both were academics. The parents emphasized equity and negotiated about everything. Unni thinks they negotiated too much and stated that adults should be adults. If Unni broke a rule the parents talked about what had happened. Unni prefers more rules and fewer negotiations. She wanted to view children as reflective individuals, and wanted her interactions with children to be respectful.

In Bernstein's terms the two FST seem to be brought up mainly by means of indirect forms of control (an invisible pedagogy) or a mixed pedagogy. However, the teaching the FST experienced in teacher education was often based on a visible pedagogy. This pedagogy contrasts strongly with the pedagogy the FST experienced in their families.

\subsection{Norway}

In the interviews the student teachers were asked why they had chosen teaching as a profession. From the nine Norwegian student teachers (NST), five said they had always wanted to become teachers. Three of the NST said they wanted to work with people, one said he started teacher education almost unintentionally and another one decided to become a teacher when he started university studies.

"Berit" a NST who had always wanted to become a teacher, says that both in lower and upper secondary school she noticed how teachers worked in different situations.

"I remember that I was thinking that I would have done this in a different way."

A male student "Anders" says that he had been conscious about wanting to be a teacher for a long time:

"First of all I like to work with pupils. Second I feel it means something else than just receiving my wages and make other persons richer on money in a company. As a teacher I can enrich hundreds and thousands [of students]"...

When The NST were asked how they would engage students in learning, five out of nine emphasized the importance of a positive learning environment and collaboration with and between students. Three NST stressed enthusiasm in their subject combined with a positive learning environment and various teaching methods. Two NST mentioned the use of examples from students' everyday experiences. Collaboratively developing explicit learning aims with students was mentioned by two NST. As a group, the NST stressed a close relationship with students more than the other groups of student teachers in this study. For example," Ole" says he wanted to be close to the students and be respectful when meeting people. Another student, "Arne" expresses his frustration during a practice term in an upper secondary school, where the students dared not respond unless they had a correct answer. This experience reinforced for Arne his commitment to developing democratic and open communication with students.

When the NST were asked about their own upbringing, they could be distinguished into those who had fixed rules, but the opportunity to negotiate (six), those who were brought up by means of a "collective agreement" about how to behave inside and outside the family (two) and one who experienced too much freedom and reduced involvement from his parents during childhood.

"Hilde" said her own upbringing influenced how she was bringing up her children. Both her parents were academics. A lot of children were living in the same street as Hilde's family.

The parents of the other children would use Hilde's parents boundaries as a benchmark for their own decisions. For example, all the parents told their children to go home in the evenings when Hilde was told to go home. Hilde says her parents were very strict. They were also strict in regards to smoking and drinking alcohol. Hilde describes her own perspective on upbringing: 
"I am a bit strict, I like that word. I make demands. It is important to give children responsibility. Children who get everything will not be successful in the long run."

All the NST who were brought up in families that used fixed rules said they had the opportunity to negotiate. While their parents tried to have clear reasons for their expectations and rules, if the NST broke the rules, they were not met with strict sanctions, but by conversations and understanding. In Bernstein's terms these NSTs had been brought up by means of a combination of hierarchic and personal forms of control.

"Tora", a third NST was raised by a mother who is pre-school teacher and a father with an education in economics. . She says she has experienced a very nice upbringing in her family. The family had a collective agreement on how to behave and how to interact with each other. They had no fixed rules, and the family had a common agreement about how to interact in the family (according to an invisible pedagogy). Tora thinks she has been brought up in a correct way, and agrees with her parents in their perspective on upbringing.

Several student teachers say they have been easy to bring up as children. Their parents did not need to enforce any strict rules in their upbringing.

\subsection{Australia}

From the Australian student teachers (AST) seven had some prior experiences of teaching, most of them from abroad. Two AST wanted a formal occupation and qualification, while another two AST said they wanted to become a teacher because it was a family friendly occupation. Two female AST said they had always wanted to become a teacher and had changed occupations, while two male students changed occupation because they loved their subject. Compared with the FST and NST, the Australian student teachers (AST) had far more prior work experiences. For example, "Mary" had been thinking of becoming a teacher for four years. She had studied law and had worked as a lawyer, but she was not happy in that profession. Mary was interested in social justice and believed that she would have more opportunities in this area as a teacher than as a lawyer.

In her interview, Mary revealed that she loved primary school and learning and was an intrinsically motivated student when she was at school. After primary school her parents had wanted her to go to a private school. While she commented that this experience was terrible, at this school she met a teacher who inspired her and gave her selfconfidence and this ultimately impacted on her desire to become a teacher.

Another Australian participant, "Ruby" had been teaching in Japan for two years. Previous to that, she had spent 18 years travelling and working in the travel industry. Because of a financial crisis her department was nearly eliminated with the stroke of a pen. Ruby says:

"I felt as I was approaching my forties and I am not married... I wanted to have a trade that I could fall back on.. .. So that is a part of it, but teaching has always been something that has come naturally to me.. in any of my roles that I have had in the travel industry they have always contained a large part of training and teaching. "

Two of the female AST had started teacher education because they viewed it as a good family occupation. For example, "Linn" had worked as an artist and singer and she had been a bank manager. When she became a mother and separated from the father of the child, she had to think of a lifestyle that would allow her to spend more time with her son. So Linn felt it was the right time for her to become a teacher. She also reflected that there had been elements of teaching in her prior occupations and she considered teaching as a natural extension to these experiences. When the ASTs were asked about how they would engage students in learning, all stressed the importance of getting students to be enthusiastic in learning. Five AST emphasized the use of the student's own experiences and their cultural background when teaching and using student-centred approaches to learning. Two ASTs underlined the importance of using testing as a way to motivate students to learn. Three AST acknowledged it was important to be enthusiastic in their subject when teaching and two AST stressed the importance of positive learning environments.

The ASTs were often influenced by their earlier work and personal life experiences. For example, "Ruby" had been a saleswoman and she stated that she used sales techniques to «sell» her subjects to students in her practice term. Ruby was inspired both by her brother and her spouse who she said were kinesthetic learners and completely unengaged in school, even if they had wonderful skills and expertise in other areas. When Ruby had her practice term, she wanted to practice learning by doing, but she was very disappointed with the experience.

She used a "chalk and talk" approach and used exercises from textbooks. She experienced discipline problems in her class. In teacher education she had learnt that if you engage kids in the subject matter, then that would reduce behavior problems. However, Ruby, in contrast, thought that you have to sort out behavior problems before you can hope to engage kids in the subject. She drew on her own personal experience as a dog trainer and drew analogies between dog training and classroom behavior management. According to Ruby, the classroom has a pack structure and unless you establish yourself as top dog in that pack structure, you will struggle to teach anything. 
Another AST, Linn who had been a singer and artist, was asked if she would 1 be an entertainer in her classroom. She agreed by stating: "Absolutely, you need to engage them" Linn drew on experiences and beliefs of her mother, a semi-retired teacher, who believed that the best teachers are creative.. Linn believed that you have to push the boundaries to engage students and you have to be flexible and create experiences as you go to engage students. Linn commented that the university and the government have pushed student-centered work. However, even if Linn agreed and prefers a constructivist approach to teaching, she thinks there should be more of a balance between more traditional ways of teaching and student-centred approaches.

When the AST were invited to describe their upbringing in their own family, four of the AST said they had been brought up with strict rules and five had experienced corporal punishment such as being smacked with a hand or a stick. For example Emma, had a mother who was a nurse and a father who was an office worker. She stated that she was scolded by her parents and was hit if she broke rules. When she was asked if she had «strict parents», she said that her parents had «strong standards». She also reflected that there is a difference between being "strict" and having "strong moral standards".

"Jon" a second AST came from a family where his mother did a lot of the child rearing. His mother came from a well-off protestant family who had their grounding in discipline. Jon stated:

«Even if she denies this till the day she dies, she would say to us «when you sit at a table you are meant to listen and not talk». Jon emphasized that his mother stressed using appropriate language and good manners and he identifies with this way of upbringing.

"Ruby" is one student teacher who disagreed with her parent's upbringing. She has been brought up in a very strict, disciplinarian, patriarchal family. None of her parents had higher education. Her father used corporal punishment, and she felt she was brought up in a cold, silent family. From her own upbringing Ruby learnt that respect was something she was compelled to give regardless of how she felt. In her interview, Ruby stated that respect is something you earn.

Three of the AST did not perceive their upbringing in their family as very strict. However, their parents wanted them to have a good education and take a degree at university.

\section{Discussion}

This paper investigates if student teachers transfer their perspectives on upbringing from their family to their professional classroom practice. It is evident from the data that what constitutes a strict upbringing is different across the three national contexts. Habitus, or the practices adopted by the collective and the individual [4], as well as educational codes are influenced by unique national and cultural contexts. The data from this research indicates that a strict upbringing in Norway and Finland means that parental rules and expectations are open for discussion and negotiation, while a strict upbringing in Australia often means fixed and rigid rules and may include corporal punishment. While corporal punishment is illegal in all the three countries, several AST report experiencing physical punishment in their early lives. In line with this authoritarian approach to parenting, some AST indicated that their parents directly influenced the selection of their first university degrees. Drawing on Bernstein's theory of visible and invisible pedagogies, an earlier study by Riksaasen [14] studied student socialization in Norwegian primary and pre-school teacher education. According to this study, the pedagogic practices the student teachers had experienced in childhood seemed to be crucial to their perspectives on both upbringing and education. Twelve of 20 student teachers in school teacher education and 13 of 20 student teachers in pre-school teacher education had similar perspectives on upbringing and discipline as their parents [14]

In the current study, the Australian group experienced the most hierarchical upbringing with strict discipline and rigid parental expectations. In Bernstein's terms the framing around the regulative discourse in the Australian families is very different when compared with the Finnish and Norwegian families. A study in progress of an international school in Norway shows how Norwegian and Australian teachers have different approaches to classroom management and classroom discipline, which supports the findings in this paper.The "progressive" upbringing described by the FST comes as a surprise in light of the conservative practices and nature of Finnish schools [11]. The tensions between the Finnish upbringing and their current educational practice can be seen in the concerns reported by the FST when they undertake their practice terms. The progressive perspectives on teaching and upbringing held by the broader population in Finland, is absent in current approaches to teacher education. Since teaching has a higher status in Finland than in most other countries, one hypothesis is that the current professional socialization in teacher education and schools (based on a visible pedagogy) may have a stronger influence on professional identity formation than for example in Norway.

National context also seems to influence recruitment to teacher education. In Australia, some people enter teacher education programs after having experiences of teaching English overseas without a formal teaching qualification. These experiences of 
teaching English in other countries have influenced some of this particular group of AST to undertake formal teaching qualifications. Another motivating factor for entering teacher education in Australia is the recent uncertain economic times. This has drawn an increasing number of career changers to education, as teaching is perceived to be a stable occupation with many opportunities for employment. Current research indicates that career changers make up $47 \%$ primary and $80 \%$ of secondary of Australian student teachers numbers. Implicitly these AST bring other professional cultures as a lens through which they analyse and understand their work as teachers [21].

Costly and limited childcare provisions in Australia serves as a motivating factor for many of the AST who perceive teaching as being 'family friendly'. This is in stark comparison to Finland and Norway where reasonably priced kindergarten places are offered to all children from one-year of age onwards.The student teachers from Norway and Finland did not discuss the 'family friendly' conditions of teaching in regards to their own motivations to becoming a teacher whereas the Australians did.

The results from this study point to different motivations to become teachers, and identify different motivations between student teachers in the three countries. The samples are small, and it is difficult to generalize, but there are some noteworthy findings. Firstly, of great interest to us was that over half of the NST have always wanted to become teachers. That means for the Norwegian group socialization into the role of a teacher had started (and continued) from when they were students in school. This aligns strongly with Britzman [5] view that student teachers' conceptions of the roles as teachers are familiar and firmly rooted in their own biography. Secondly, the FST came to teaching because of their focus and connection to their specific discipline area rather than a strong commitment to pedagogy. This finding is supported by Tirri and Urbani's [20] research that found 280 student teachers across nine different subjects all viewed subject knowledge as more important than pedagogical knowledge. This highlights the privileging of deep content knowledge within the education system in Finland.

\section{Conclusion}

This study shows that different economic and cultural conditions influence motivation and the formation of teacher professional identity in these three different countries. Professional identity formation takes place in an interplay between the individual, their prior experiences and their sociocultural context. Student teachers acquire habitus as a product of their experiences of families and upbringing as well as their understandings of schooling and educational systems. Using a comparative study, this paper provides a nuanced understanding of professional socialization and identity formation across Finland, Norway and Australia. However, the sample of this study is small, and draws only on interview data. While the interviews elicit rich information and insights they do focus on ideologies of teaching and upbringing. To develop a deeper understanding of how these impact practice, further research should also seek to include observations of the student teacher's teaching during practice terms as well as interviews.

\section{References}

[1] Beijaard, D, Meijer, P.C \&Verlop, N.(2004). Reconsidering research on teachers' professional identity. Teaching and Teacher Education 20: 107-28.

[2] Bernstein, B.(1977): Class Codes and Control. Vol. III. Towards a Theory of Educational Transmissions. London: Routledge.

[3] Bernstein, B.(1990). The structuring of pedagogic discourse. Class, Codes and Control. Vol. IV. London: Routledge.

[4] Bourdieu, P.(1990. The Logic of Practice. Cambridge:Policy Press.

[5] Britzman, D.(1992). The terrible problem of knowing thyself: toward a poststructural account of teacher identity. Journal of Curriculum Teaching, 9, 3, pp.23-46.

[6] Bukor, E. (2015). Exploring identity construction from a holistic perspective: reconstructing and reconnecting personal and professional selves. Teachers and Teaching: Theory and Practice. 21, 305-327. doi: 10.1080/13540602.2014.953818

[7] Czerniawski, G.(2011). Emerging teachers-emerging identities: trust and accountability in the construction of newly qualified teachers in Norway, Germany, and England. European Journal of Teacher Education.Vol. 34, No. 4, pp 431-447.

[8] Hargreaves, A. (1994).Changing Teachers, Changing Times. Teachers' work and culture in postmodern age. London.

[9] Hargreaves, A. \& Goodson, I. (1996). Teachers' professional lives: aspirations and actualities. In I. Goodson \&A. Hargreaves (eds). Teacher's Professional Lives. London: Falmer.

[10] Harker, R. \& May, S.A.(1993). Code and Habitus. Comparing the Accounts of Bernstein and Bourdieu. British Journal of Sociology of Education, 14 (2)pp 169 178.

[11] Haug, P. (2008); Dagsavisen. Oslo 25.09.2008. 
[12] Miles, M. B. \& Huberman, A. M. (1994). Qualitative data analysis: An expanded sourcebook, Beverley Hills, CA: Sage Publications.

[13] Riksaasen, R.(2014). Usynlig pedagogikk og ettergivenhet. Fører ettergivenhet blant lærere til mange umotiverte elever? I Riksaasen, R. og Langset,I. (red.) (2014) Endring av praksis i klasserommet. En artikkelsamling om utviklingsarbeid, samarbeid, erfaring og forskning. Trondheim: Akademika

[14] Riksaasen, R. (1999). Visible and Invisible Pedagogies in Teacher Education. A comparison of Norwegian primary and pre-school teacher education. Dr.polit. avhandling. NTNU Trondheim. Fakultet for samfunnsvitenskap og teknologiledelse. Institutt for sosiologi og statsvitenskap.

[15] Riksaasen, R.(2007). En sammenligning av norsk og amerikansk lærerutdanning. I Guldal, T.M.Lillemyr, O.F. Løkken.G., Naastad, N. \&Rønning, F. Fou i Praksis 2007. Trondheim: Tapir akademisk forlag. pp 293-305.

[16] Sachs, J.(2005). Teacher education and the development of professional identity: Learning to be a teacher. In P. Denicolog \&M.Kpmpf (Eds.) Connecting policy and practice. : Challenges for teaching and learning in schools and universities (pp 5-21). Oxford;U.K:Routledge.

[17] Simola, H.(2005). The Finnish miracle of PISA: historical and sociological remarks on teaching and teacher education. Comparative Education. Vol. 42, No.4, November 2005, p.455-470.

[18]Stephens, P., Tønnesen, E. \& Kyriacou, C.(2004). Teacher Training and Teacher Education in England and Norway: a comparative study of policy goals. Comparative Education, 40.

[19] Tjeldvoll, A.(2002). The Decline of Educational Populism in Norway. European Education, 34.

[20] Tirri, K.\&Ubani,M.(2013). Education of Finnish student teachers for purposeful teaching. In Journal of Education for Teaching. Vol. 39, No.1. February 2013, 2129.

[21] Williams, J. (2010). Constructing a new professional identity: Career change into teaching. Teaching and Teacher Education, 26, 639-647

[22] Zeichner K., \& Gore, J. (1990). Teacher socialisation. In W. R. Houston, M. Haberman, J. P. Sikula, and Association of Teacher Educators (Eds.), Handbook of research on teacher education (pp. 329-348). New York: Macmillan. 